\title{
Reproduction and larval development of Manayunkia aestuarina (Bourne, 1883) (Polychaeta, Sabellidae) in a coastal region of the southern Baltic
}

\author{
A. Bick \\ Universität Rostock, FB Biologie, Allgemeine \& Spezielle Zoologie; Universitätsplatz 5, \\ D-18051 Rostock, Germany
}

\begin{abstract}
The reproduction and larval development of Manayunkia aestuarina, a polychaete typical of brackish lenitic waters, was studied in a tideless shallow region on the south Baltic coast in 1990. Reaching abundances of up to 50000 ind. $/ \mathrm{m}^{2}$, it is an important element of the benthic community in this area. Reproduction started in late March/early April, when the females deposited their eggs in the tubes. On the average, 4 (maximum: 16) developing embryos were found in a maternal tube during the reproduction period. The females probably produced a mean of about 12 eggs. Development in the maternal tube lasted about 8 weeks. The first juveniles were found outside the tubes in mid-May. The survival rate during the first few weeks was estimated to be $15-20 \%$. After reproducing, the adult animals survived until October. The changes involved in the development from eggs to juvenile animals are illustrated by drawings.
\end{abstract}

\section{INTRODUCTION}

Manayunkia aestuarina is a character species of shallow lenitic waters, especially in European and North American boreal brackish regions (Muus, 1967; Kendall, 1979; Bell, 1982; Bishop, 1984; Junoy \& Viéitez, 1990). Reaching enormous abundances in some places (up to $1.5 \times 10^{6}$ ind $/ \mathrm{m}^{2}$ ), the species is an important component of the benthic community. Together with the ostracode Cyprideis littoralis, it is characteristic of eulittoral and supralittoral soft bottoms in the North and Baltic Seas (Remane, 1940). In view of this, it is astonishing that the biology of $M$. aestuarina has received little attention in the past. Although Lewis (1968) described its feeding mode and tube, and both Forsmann (1956) and Schütz (1965) mentioned some aspects of its reproduction, reproduction and larval development have never been described in detail. The present paper describes larval development of $M$. aestuarina within the maternal tube in a coastal water of the south Baltic.

\section{MATERIAL AND METHODS}

Our studies were undertaken in a tideless water in Mecklenburg Bay on the south Baltic coast (Fig. 1) in 1990. Samples were collected at monthly intervals outside of the reproduction period, and every two weeks from April to August. The samples were taken by corer $\left(2.83 \mathrm{~cm}^{2}\right)$. The patchiness of the distribution was compensated for by pooling four cores at a time to form a haul $\left(=11.34 \mathrm{~cm}^{2}\right)$. At least three hauls (i.e. 12 cores) were 


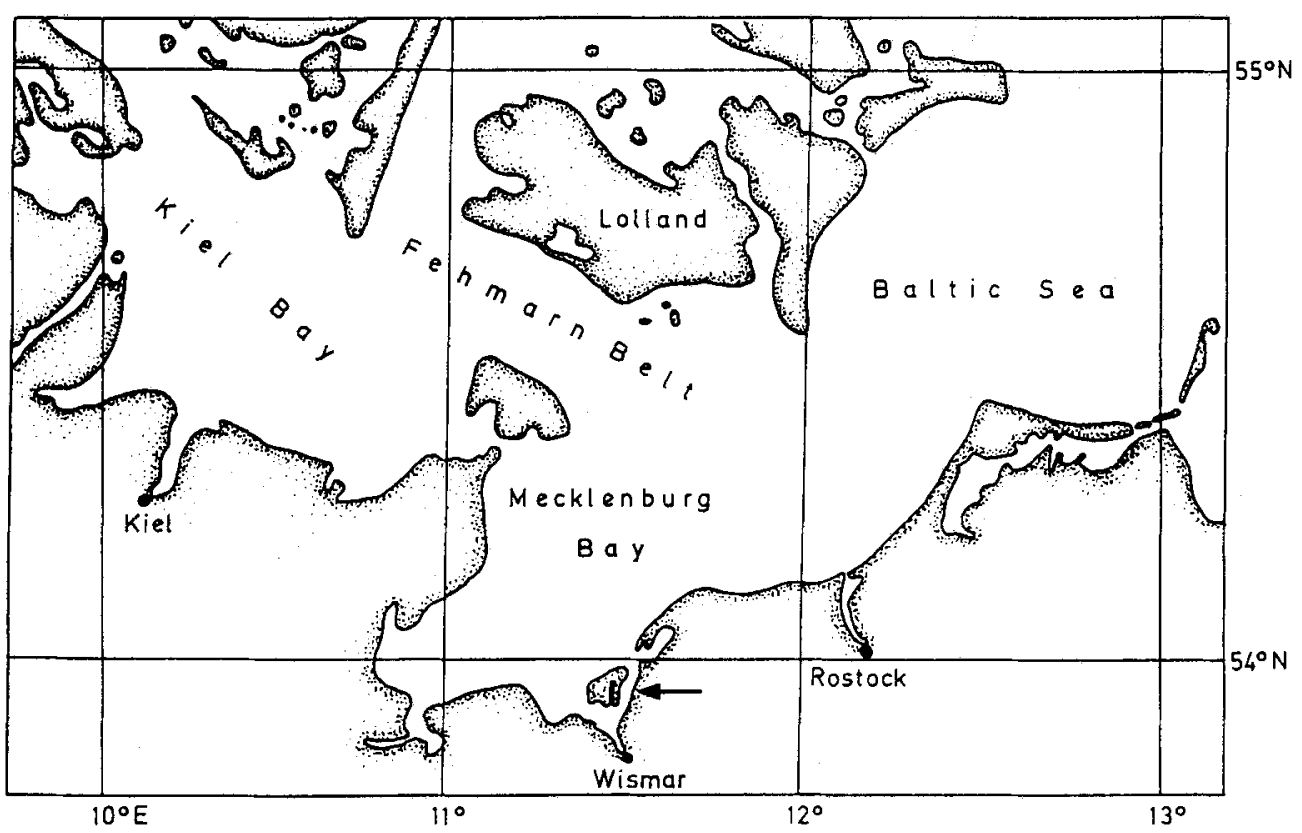

Fig. 1. Location of the investigation area in the south Baltic Sea

taken at each sampling. The hauls were fixed with borax-buffered formaldehyde $(4 \%)$ and sieved ( $0.1 \mathrm{~mm}$ mesh size) at the laboratory. The water temperature was measured, and sediment samples were taken for determining grain size and organic content on each sampling date. After sieving, the animals were removed from the samples under a dissecting microscope $(20 \times$ magnification), and the age and sex were determined at a magnification of $100 \times$ under a microscope. Age determination was based on the number of abdominal hooks (Bick, 1995), but sexing was only possible after gametogenesis when eggs could be seen in the 4 th setiger, and when the 6 th to 8 th thoracic segments of males were full of spermatozoa. The tubes of Manayunkia aestuarina were also examined for the presence of eggs and larvae; the numbers per tube and the average number per sample were calculated. The various developmental stages were also measured at a magnification of $100 \times$ or $200 \times$.

\section{RESULTS}

Both temperature and salinity in the investigation area are subject to annual variation (Fig. 2). The water temperature varied between 0.9 and $20.8^{\circ} \mathrm{C}$ during the study, and the salinity between 10.6 and $16.7 \%$. The organic content of the sediment varied between 1.2 and $2.5 \%$ DW, and the mean grain size between 0.14 and $0.25 \mathrm{~mm}$.

Manayunkia aestuarina (Fig. 3) was among the most common macrozoobenthos representatives in the investigation area. The average abundance during the year was about 35000 ind. $/ \mathrm{m}^{2}$ (Fig. 4). No distinct annual variation was found, but there was 


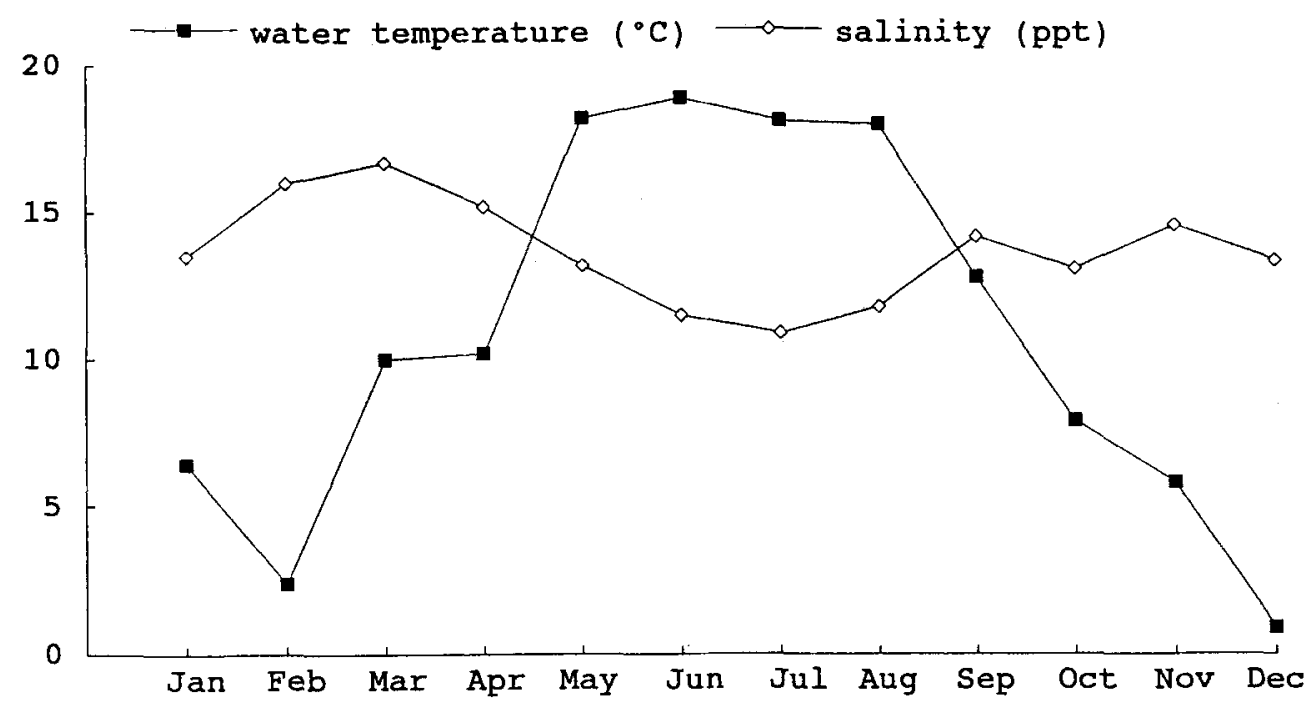

Fig. 2. Seasonal temperature and salinity variations in the investigation area in 1990

considerable variation among sampling dates, and the standard deviations were also high.

Analysis of the structure and development of the population showed that gametogenesis started in January. Males appear to reach sexual maturity prior to females, and the largest number of mature males relative to the total population were recorded in March. However, the proportion of mature females continued to increase until mid-May (Fig. 5).

The first eggs were found in the tubes of females in March. Thereafter, the proportion of females with various developmental stages in their tubes increased from $50 \%$ in early April to $72 \%$ at the end of May. Larvae were found in the tubes until 9th August. The reproduction period reached its climax in mid-May, when it was possible to identify the sex of virtually all individuals.

None of the tubes contained more than 3 eggs at the end of March, which suggests that a clutch consists of about 3 eggs. On the average, 4 eggs or 4 embryos were found in the tubes of females in April and May (Fig. 6). The largest number of eggs and developing embryos found in a single tube was 16 in mid-May (Figs 6, 9). This indicates that between 4 to 8 clutches had been produced by that time.

The adult animals remained alive after releasing their sexual products, but sexing was then no longer possible. The sex ratio was about $1: 1$.

The first burrowing juveniles were found in mid-May, i.e. development in the maternal tube took about 8 weeks. The proportion of juveniles in the total population increased thereafter and exceeded $50 \%$ by mid-July.

The youngest developmental stages generally occupied the front part of the tube with the more advanced embryos behind them. All larvae "faced" the tube mouth, and all eggs and larvae were joined by a mucous coating (Fig. 7). 

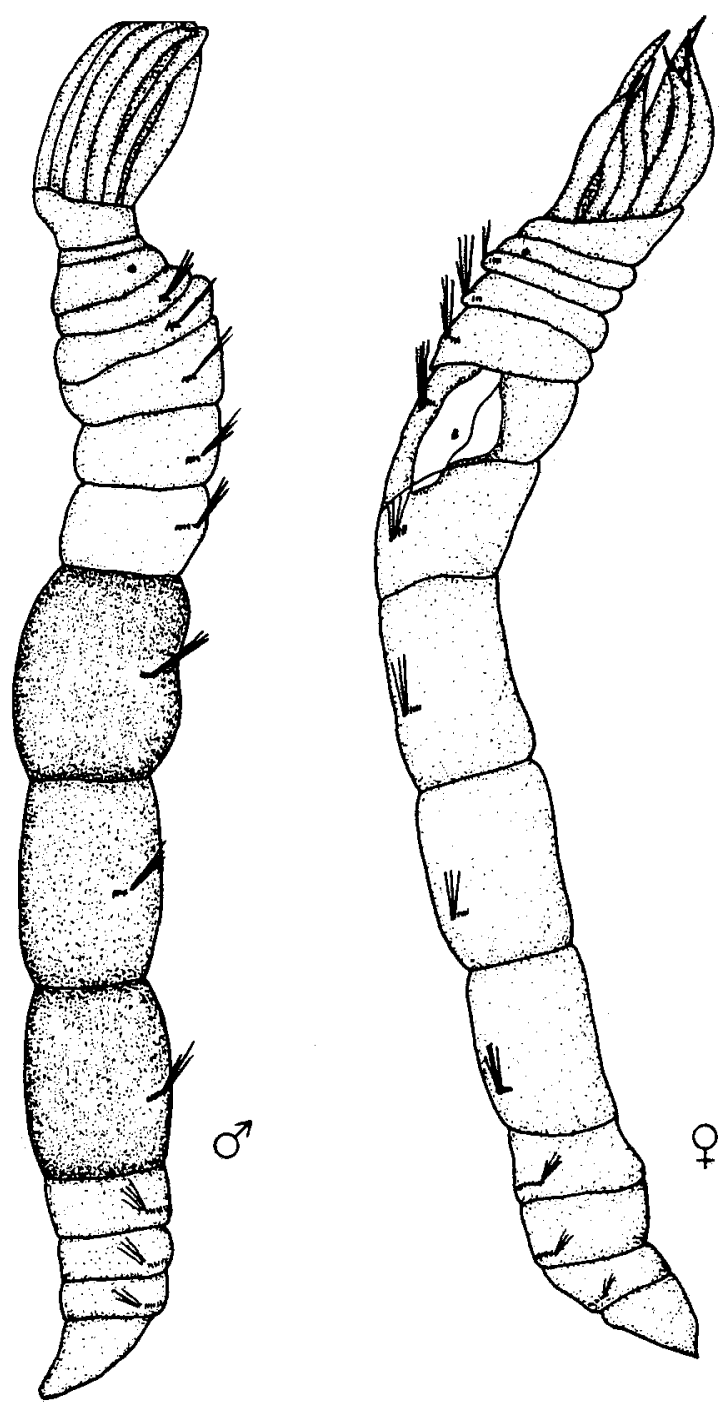

Fig. 3. Manayunkia aestuarina: male and female, both mature; about $4 \mathrm{~mm}$ long

Growth during development from eggs to juveniles in the maternal tube is shown in the length histograms (Fig. 8). The smallest stages (eggs) were $235 \mu \mathrm{m}$ long, and larvae longer than $660 \mu \mathrm{m}$ were rarely found in the tubes (maximum length: $760 \mu \mathrm{m}$ ). The histograms show why the first juveniles were found outside the maternal tubes in midMay (Fig. 5): larvae from the first clutch did not reach their maximum length until about this time. A second clutch was laid about 4 weeks after the first (cf. also Fig. 6). Since there was no synchronous development within clutches, and since the number of eggs per clutch varied, it was not possible to ascertain just how many clutches were produced. The lengths of the 16 young $M$. aestuarina developing within a single tube are shown in 


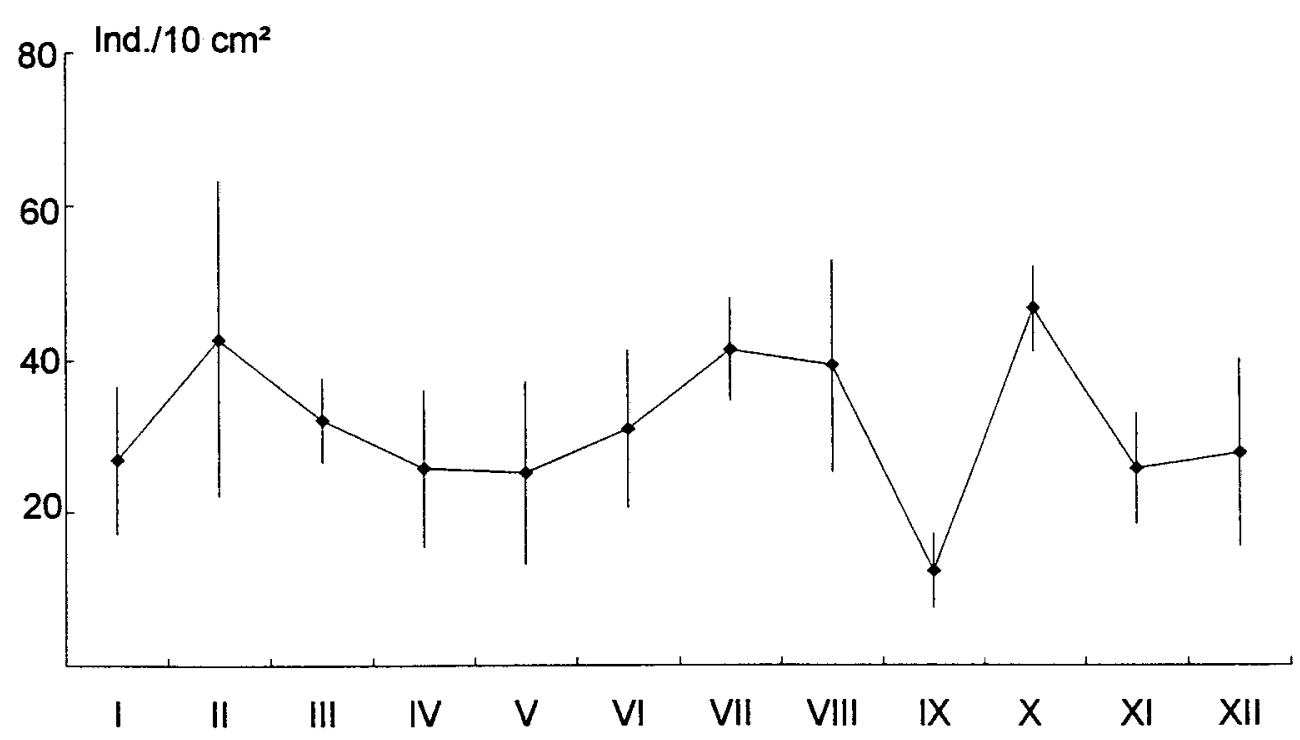

Fig. 4. Mean densities $(\mathrm{x} \pm \mathrm{sd}$ ) of $M$. aestuarina in the investigation area in 1991

Figure 9. Owing to variability in egg size and growth rate and to the possibility of mortality among embryos, we cannot say exactly when subsequent clutches were produced and how large they were, but eggs can obviously be produced until July at least.

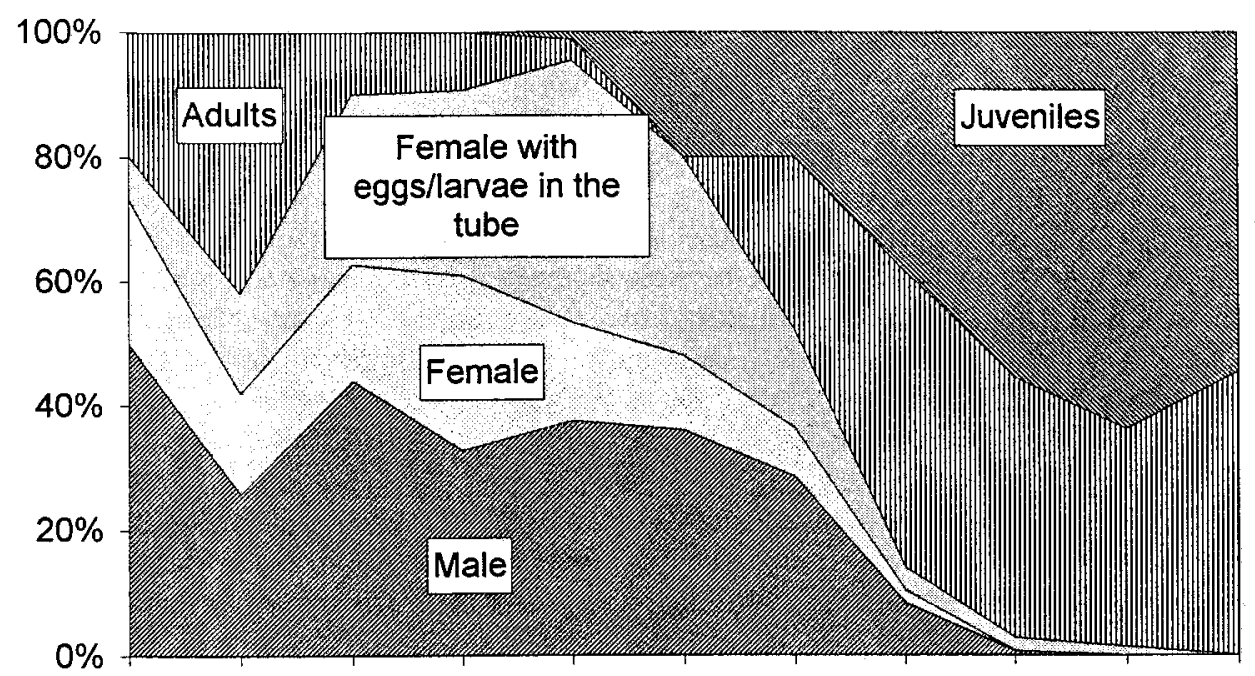

$\begin{array}{lllllllllll}20.3 & 3.4 & 20.4 & 3.5 & 16.5 & 28.5 & 13.6 & 1.7 & 19.7 & 9.8 & 28.8\end{array}$

Fig. 5. Population structure of $M$. aestuarina in the investigation area in 1990 


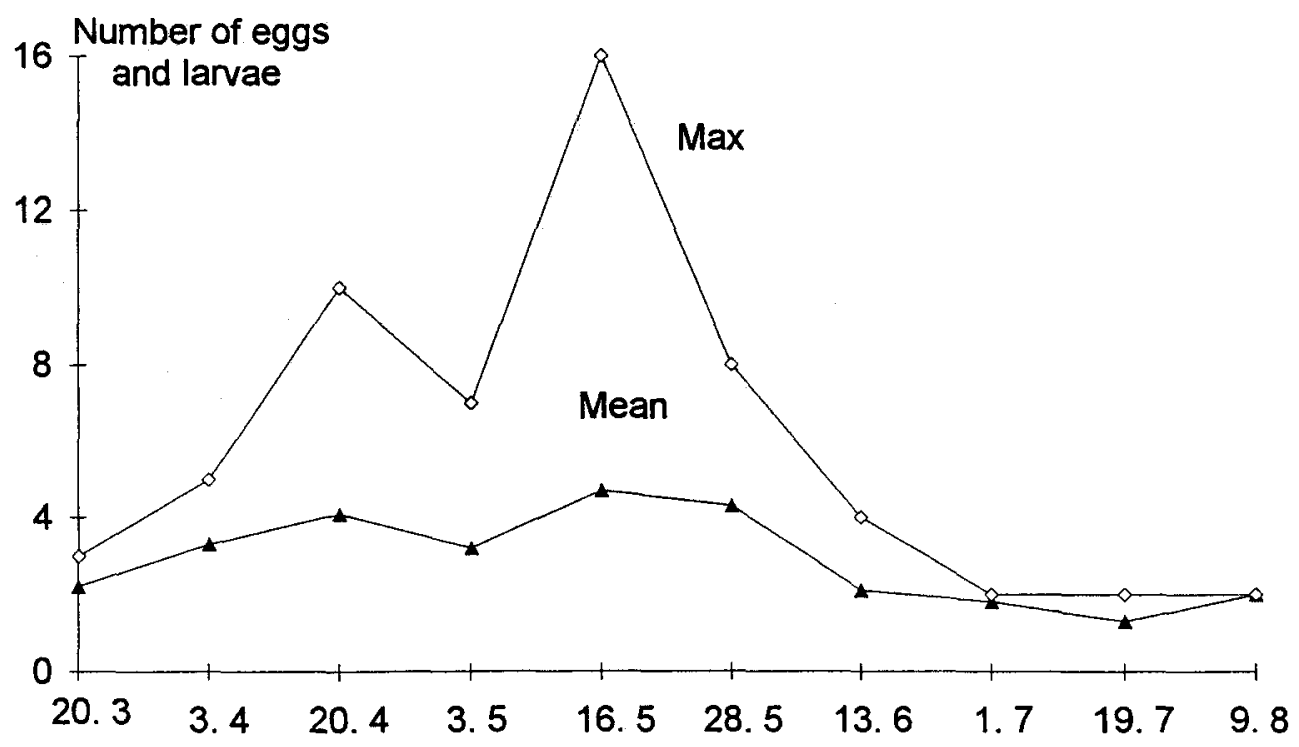

Fig. 6. Mean and maximum numbers of eggs and larvae per tube of female $M$. aestuarina

Some of the developmental stages we found are shown in Figure 10. Early ovoid development was marked by increasing length and, initially, decreasing width. The tentacular crown started developing relatively early, its first signs being the appearance of protuberances. External segmentation was already becoming apparent as the two trunks of the tentacular crown were developing. The radioli and setae developed more or less concurrently. Capillary setae appeared in the thoracic region, starting at the front end, before thoracic segmentation had been completed and abdominal segmentation had started. Formation of the hooks started after segmentation had been completed. The juveniles left the maternal tube at this point.

Adult and juvenile individuals were found side by side after the end of the reproduction period (Fig. 11), the adult animals obviously surviving until October. By November, juveniles had developed almost the same number of abdominal hooks as the adults and were also almost the same size. Little growth took place in winter, the mean number of abdominal hooks increasing only slightly from November to February. The correlation between the number of hooks and the maximum width of the front third of the body is shown in Figure 12.

\section{DISCUSSION}

Manayunkia aestuarina is a character species of eulittoral and supralittoral soft bottom communities in the brackish boreal waters of North America and Europe. Only Harris (1970) reported that stable populations also exist in marine regions. However, his illustration of $M$. aestuarina bears little resemblance to the species. More specifically, the pinnules he shows in the tentacular crown are too numerous for $M$. aestuarina. The species he described is probably a different member of the Fabricinae.

The abundances found in both European and North American estuaries are of a level 

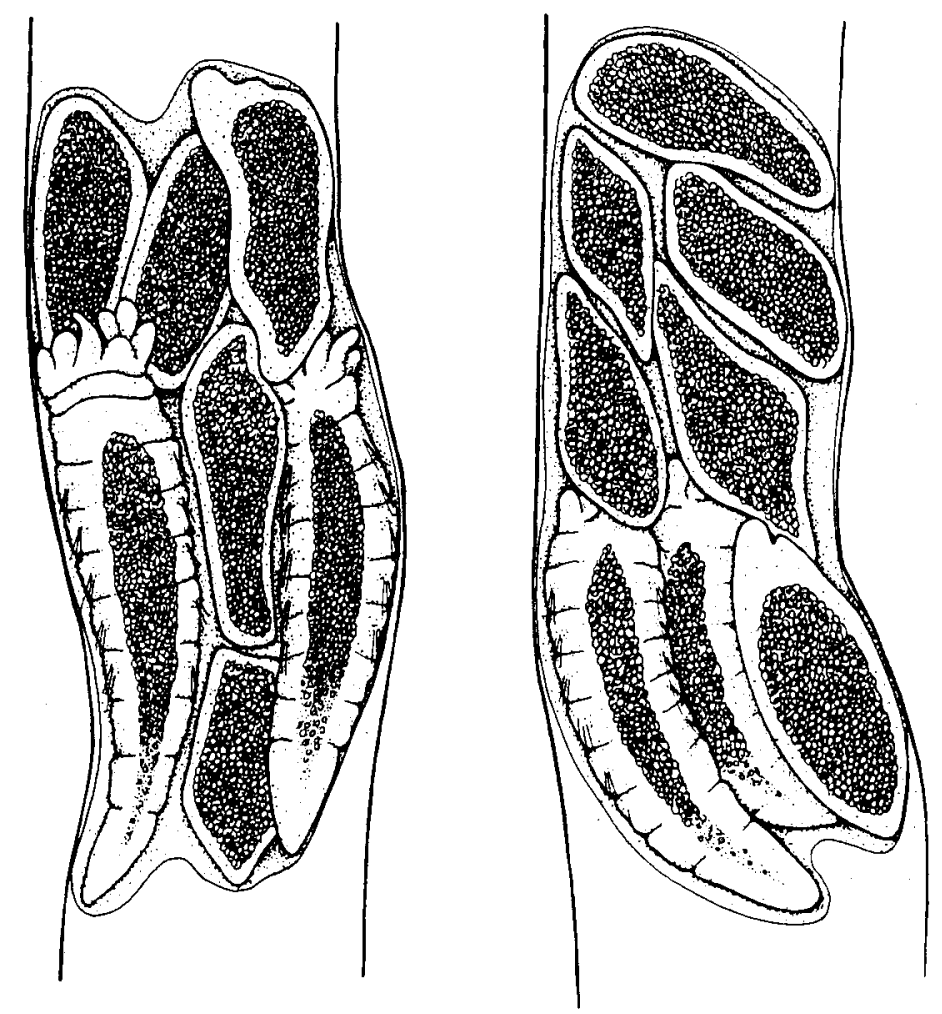

Fig. 7. Typical positions of developmental stages in the tubes of female $M$. aestuarina; the stages are between 240 and $520 \mu \mathrm{m}$ long. The larvae are arranged with the front ends facing the tube mouth

normally reached only by meiobenthic species. Bagheri \& McLusky (1982) reported abundances of up to $1.5 \times 10^{6} \mathrm{ind} . / \mathrm{m}^{2}$ in the Forth estuary, and Eckmann (1979) found up to $0.5 \times 10^{6}$ ind. $/ \mathrm{m}^{2}$ in North America. Abundances of these magnitudes are unknown in the Baltic Sea, where the species rarely exceeds 50000 ind. $/ \mathrm{m}^{2}$. Nevertheless, $M$. aestuarina is also a character species of shallow lenitic regions in this area.

The high standard deviations recorded in our investigation area despite pooled sampling indicate that the distribution of $M$. aestuarina is patchy (Fig. 4). Moreover, the considerable variation of the abundance in time also masked the annual population dynamics of the species in this area. However, neither Bell (1982) nor Kendall (1979) reported marked seasonal variations in South Carolina and the Tee estuary, respectively.

Sediment properties appear to be the decisive factor affecting the macroscale and mesoscale distribution of $M$. aestuarina. Previous studies in our investigation area have shown that changes in the organic content of the sediment lead to changes in the 
A. Bick
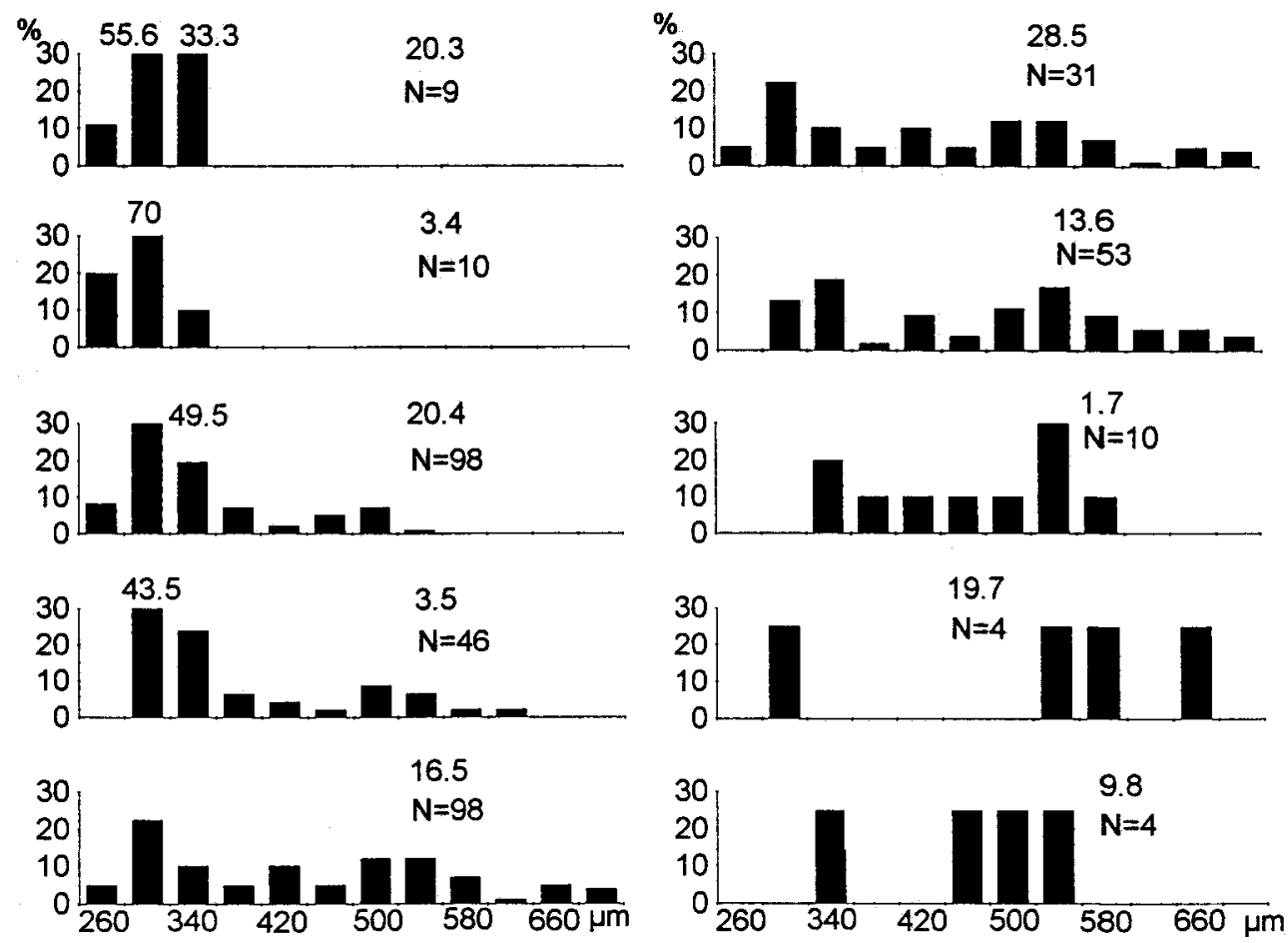

Fig. 8. Length histograms for developmental stages in the tubes of $M$. aestuarina females (each sizeclass $40 \mu \mathrm{m}$, arbitrarily choosen)

abundance of this species. Reduction of the organic content from about $1.8 \%$ to $1.0 \%$ was followed by a reduction in abundance from about 16000 to $6000 \mathrm{ind} . / \mathrm{m}^{2}$. Sediment quality also appears to influence reproduction.

Schütz (1965) reported that $M$. aestuarina reproduces from late May to August in the Baltic Sea, with some delay in more northern latitudes owing to the longer winters and lower water temperatures in spring. In the North Sea, reproduction reportedly starts in March and ends in summer. Although Bagheri \& McLusky (1982) stated that recruitment takes place from May to July, Bell (1982) found the first juvenile worms in April. This discrepancy in dates is obviously due to differences in water temperatures, which rarely drop below $10^{\circ} \mathrm{C}$, even in winter along the coast of South Carolina, and can reach $20^{\circ} \mathrm{C}$ even in April. Reproduction is obviously also influenced by temperature: low temperatures in winter and spring delay both maturation and the rate of larval development. The temperatures measured in the south Baltic in spring 1990 were about the same as the long-term mean, and the beginning and course of reproduction is probably similar in the estuaries of both the North Sea and the Baltic. The developmental times of 2 and 2 to 4 weeks in the maternal tube reported for the related species Fabricia sabella and M. caspia, respectively, (Nausch, 1982 and Marinescu, 1964) and for M. aestuarina in a salt marsh in South Carolina (Bell, 1982) are obviously shorter than in boreal regions, where a brooding period of 8 to 10 weeks is typical. Although temperature does influence 


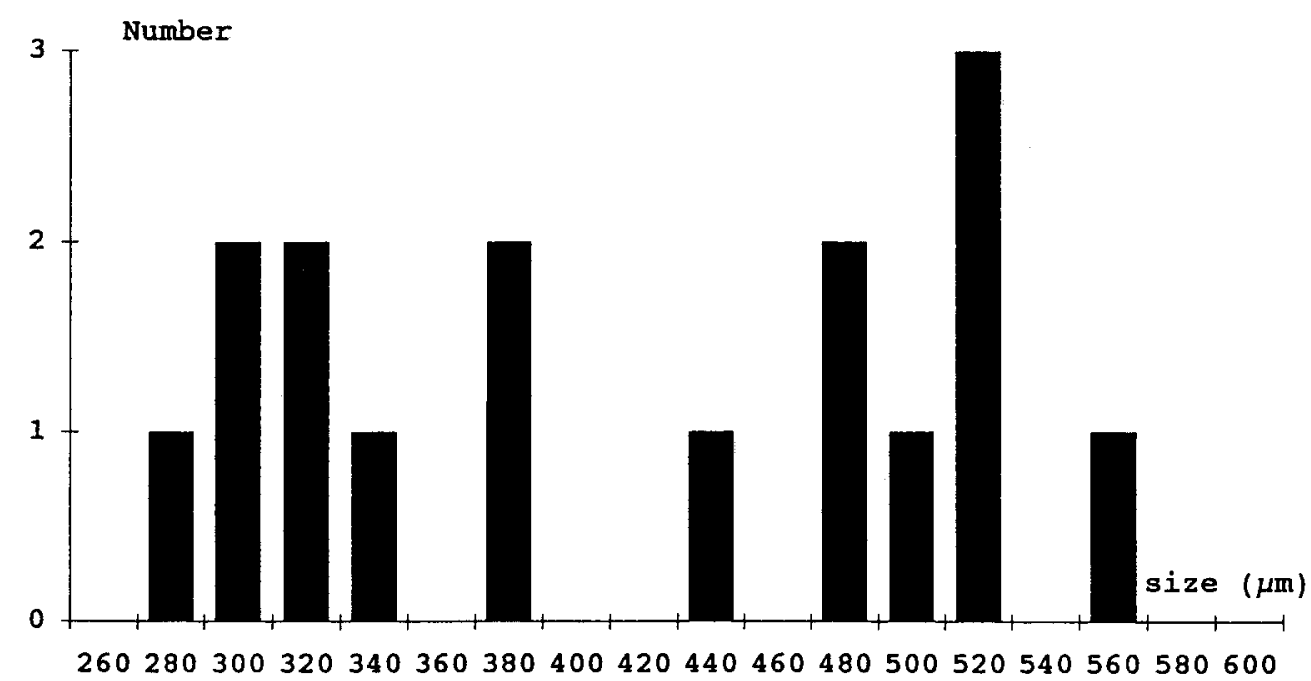

Fig. 9. Length distribution of developmental stages $(N=16)$ in the tubes of a female $M$. aestuarina on May 16th, 1991 (each size-class $20 \mu \mathrm{m}$, arbitrarily chosen)

larval development (e.g. Anger et al., 1986), we do not think that a minor temperature increase would reduce the development time by half.

The sex ratio (females:males) of 3-5:1 reported by Forsman (1956) and Schütz (1965) could not be confirmed for our investigation area. The sex ratio remained about 1:1 during the entire reproduction period. However, Schütz (1965) also found a supralittoral population in which males formed a distinct majority. This discrepancy may signify regional differences.

The 16 eggs and embryos, at different stages of development, that we found in a single tube is the highest number ever reported. Schütz (1965) and Bell (1982) never found more than 8 and 12 embryos, respectively, in a single tube. However, our data permit no conclusions to be drawn regarding average fecundity. The mean number of eggs or larvae found in a tube during the reproduction period was about 4 . Assuming that the average clutch consists of three eggs and that one clutch is produced about every 4 weeks (cf. Fig. 8), we estimate that a female may produce about 12 eggs during the reproduction period. However, the numbers that failed to develop or were lost during sample collection and handling are unknown. Figures 4 and 5 show, however, that the abundance of $M$. aestuarina in the investigation area doubled after mid-July, and that about half the population consisted of juveniles. In view of the sex ratio of $1: 1$, this means that 2 juveniles per female had survived at that time. Since the investigation area is fairly sheltered, the exchange of water is only slight and the juveniles settle and burrow their tubes only shortly after leaving those of the females, i.e. apparently without significant migration. It is unlikely that large numbers immigrate or emigrate. Therefore, the survival rate of juveniles must have been about 15 to $20 \%$ at that time.

At temperatures between 15 and $20^{\circ} \mathrm{C}$, development from the egg to a juvenile worm living on its own takes about 8 weeks. External segmentation, the formation of a 

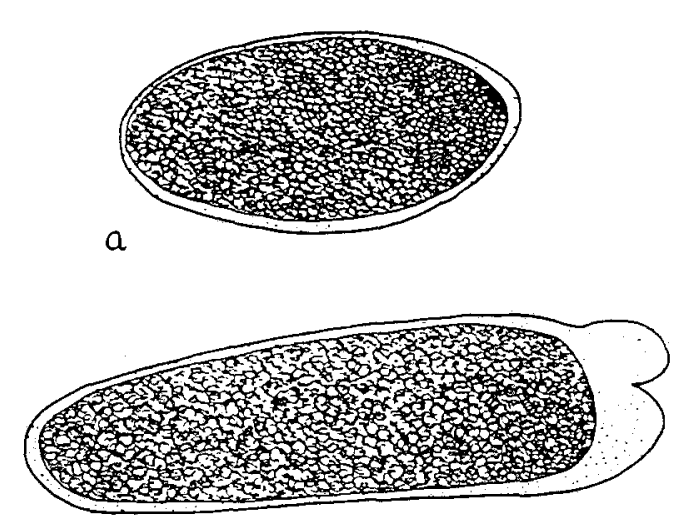

b

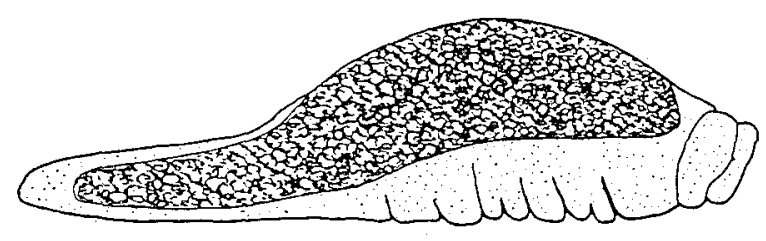

$c$

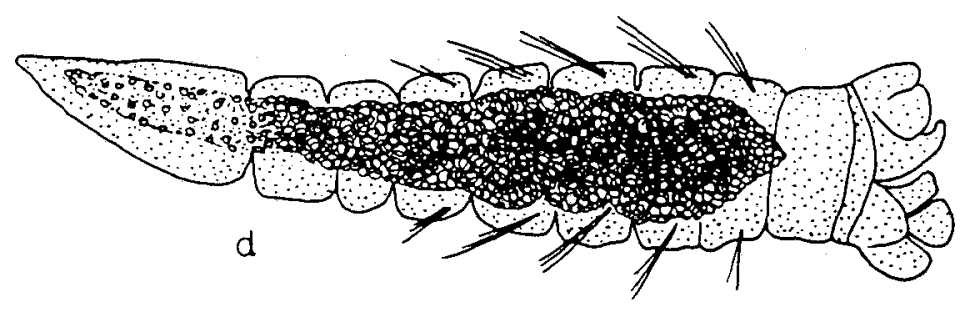

Fig. 10. Developmental stages of $M$. aestuarina. a: early stage $(276 \times 138 \mu \mathrm{m})$; b: start of tentacular crown development $(388 \times 125 \mu \mathrm{m})$; c: onset of external segmentation, lateral view $(480 \times 140 \mu \mathrm{m})$; $\mathrm{d}$ : gradual abdominal segmentation and onset of setal development $(498 \times 115 \mu \mathrm{m})$

tentacular crown and the appearance of the first setae and hooks take place within this period. No ciliary girdles were observed growing on the larval bodies. The cilia of the tentacular crown and around the fecal pit obviously develop after the maternal tube has been left. The oral aperture is already present by this time, and the animals start feeding actively. It seems likely that larval food reserves are virtually exhausted when this transition takes place. Abdominal segmentation and setation are completed after the maternal tube has been left.

The number of abdominal hooks is a convenient guide to age. However, in connection with taxonomic studies it is necessary to take into account the variation in the number of abdominal hooks with increasing age (Bick, 1995). This is particularly 


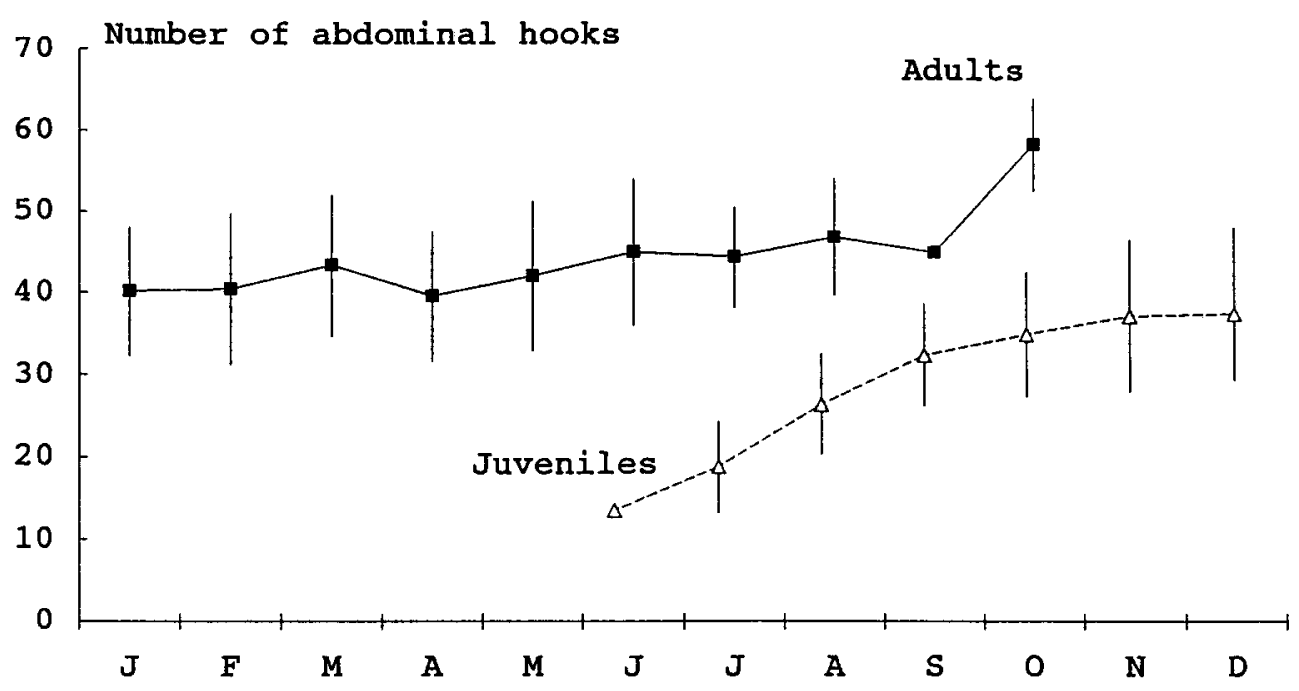

Fig. 11. Growth curve of $M$. aestuarina during the investigation period based on the number of abdominal hooks ( $\mathrm{x} \pm \mathrm{sd}, \mathrm{N}=559$ )

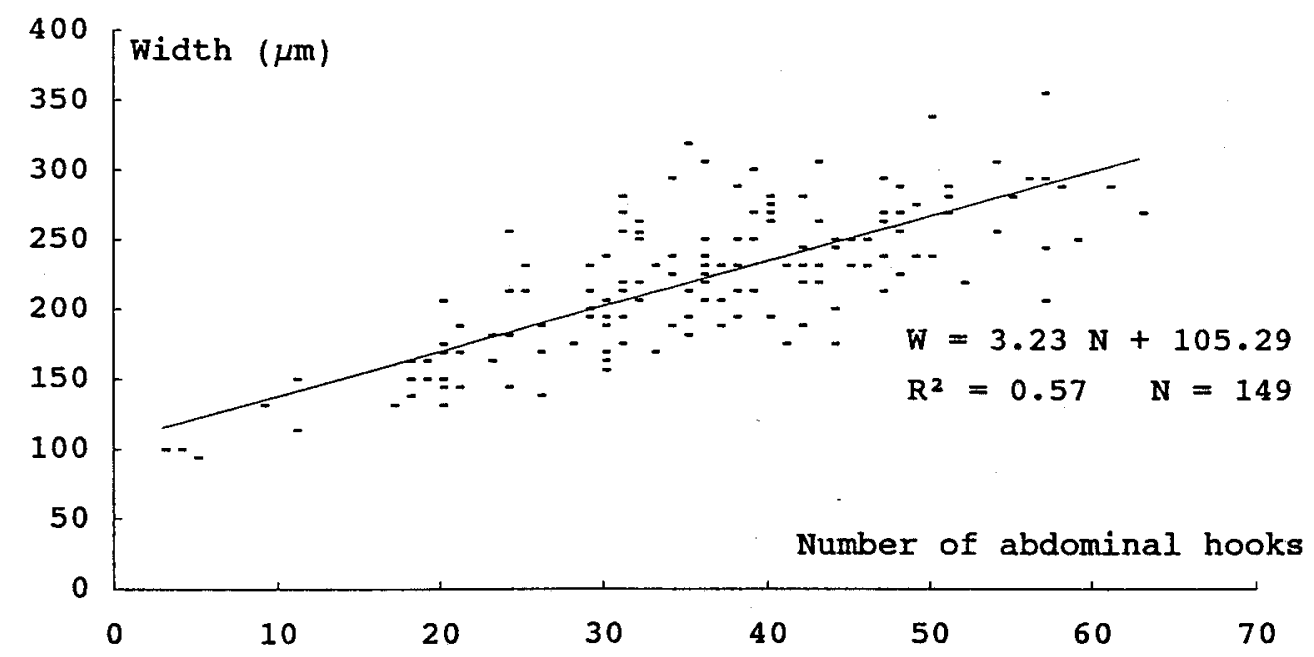

Fig. 12. Correlation between the number of abdominal hooks and segment width of $M$. aestuarina in the investigation area

important in the case of the Fabricinae since the shape and number of certain hooks and setae are of diagnostic importance in this group (Annenkova, 1928; Banse, 1956; Fitzhugh, 1983).

Acknowledgements. I thank Dr. H.-D. Franke of the Biologische Anstalt Helgoland for his interesting comments, and B. Patchett for his help in translating the manuscript. 


\section{LITERATURE CITED}

Anger, K., Anger, V. \& Hagmeier, E., 1986. Laboratory studies on larval growth of Polydora ligni, Polydora ciliata, and Pygospio elegans (Polychaeta, Spionidae). - Helgoländer Meeresunters. 40, 377-395.

Annenkova, N., 1928. Über die pontokaspischen Polychaeten. 2. Die Gattungen Hypaniola, Parhypania, Fabricia, und Manayunkia. - Annln Mus. Zool. Leningrad 30, 13-20.

Bagheri, E. A. \& McLusky, D. S., 1982. Population dynamics of oligochaetes and small polychaetes in the polluted Forth estuary ecosystem. - Neth. J, Sea Res. 16, 55-66.

Banse, K., 1956. Beiträge zur Kenntnis der Gattungen Fabricia, Manayunkia, und Fabriciola (Sabellidae, Polychaeta). - Zool. Jb. (Syst. Ökol. Geogr. Tiere) 84, 415-438.

Bell, S. S., 1982. On the population biology and meiofaunal characteristics of Manayunkia aestuarina (Polychaeta: Sabellidae: Fabricinae) from a South Carolina salt marsh. - Estuar. coast. mar. Sci. $14,215-221$.

Bick, A., 1995. Größenabhängige Veränderungen von morphologischen Merkmalen bei Marenzelleria viridis (Spionidae) und Manayunkia aestuarina (Sabellidae). - Mitt. hamb. zool. Mus. Inst. $92,41-53$.

Bishop, T. D., 1984. A range extension for Manayunkia aestuarina (Bourne, 1883) (Polychaeta: Sabellidae) to the Gulf coast of the United States with a review of previous habitat information. Gulf Res. Rep. 7, 389-392.

Eckman, J. E., 1979. Small-scale patterns and processes in a soft substrate interstitial community. J. Mar. Res. 37, 241-257.

Fitzhugh, K., 1983. New species of Fabriciola and Fabricia (Polychaeta: Sabellidae) from Belize. Proc. biol. Soc. Wash. 96, 276-290.

Forsman, B., 1956. Notes on the invertebrate fauna of the Baltic. - Ark. Zool. 9, 389-419.

Harris, T., 1970. The occurrrence of Manayunkia aestuarina (Bourne) and Mercierella enigmatica Fauvel (Polychaeta) in non-brackish localities in Britain. - J. exp. mar. Biol. Ecol. 5, 105-112.

Junoy, J. \& Viéitez, J. M., 1990. Manayunkia aestuarina (Bourne, 1883) (Polychaeta, Sabellidae), en la Ria de Foz (Galicia, España). - Boln R. Soc. esp. Hist. nat. (Sec. Biol.) 86, 83-94.

Kendall, M. A., 1979. The stability of the deposit feeding community of a mudflat in the River Tees. Estuar. coast. mar. Sci. 8, 15-22.

Lewis, D. B., 1968. Feeding and tube-building in the Fabriciinae (Annelida, Polychaeta). - Proc. Linn. Soc. Lond. 179, 37-49.

Marinescu, V. P., 1964. La reproduction et le développement des polychétes reliques ponto-caspiens du Danube: Hypaniola kowalewski (Grimm) et Manayunkia caspia. - Revue roum. Biol. (Sér. Zool.) 9, 87-100.

Muus, B. J., 1967. The fauna of danish estuaries and lagoons. Distribution and ecology of dominating species in the shallow reaches of the mesohaline zone. - Meddr Danm. Fisk. -og Havunders. 5, 3-316.

Nausch, M, 1982. Experimentell-ökologische Untersuchungen an Polychaetenspecies der DarßZingster Boddengewässer. Diss. Univ. Rostock, $138 \mathrm{pp}$.

Remane, A., 1940. Einführung in die zoologische Ökologie der Nord- und Ostsee. - Tierw. NordOstsee 1a, 1-238.

Schütz, L., 1965. Über Verbreitung, Ökologie und Biologie des Brackwasserpolychaeten Manayunkia aestuarina (Bourne), insbesondere an den Küsten Schleswig-Holsteins. - Faun. Mitt. Norddeutschl. 2, 226-234. 